\title{
CREATING THE EMPRESS: \\ Politics and Poetry in the Age of Catherine II
}

Vera PROSKURINA 
Library of Congress Cataloging-in-Publication Data:

A catalog record for this book as available from the Library of Congress.

The book is supported by Mikhail Prokhorov Foundation (translation program TRANSCRIPT).

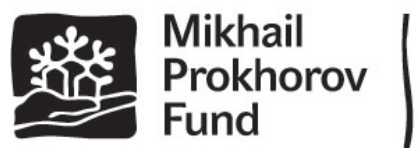

Copyright (C) 2011 Academic Studies Press

All rights reserved

ISBN - 978-1-936235-50-6

Book design by Ivan Grave

Published by Academic Studies Press in 2011

28 Montfern Avenue

Brighton, MA 02135, USA

press@academicstudiespress.com

www.academicstudiespress.com 


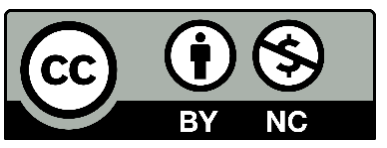

Effective December 12th, 2017, this book will be subject to a CC-BY-NC license. To view a copy of this license, visit https://creativecommons.org/licenses/by-nc/4.0/. Other than as provided by these licenses, no part of this book may be reproduced, transmitted, or displayed by any electronic or mechanical means without permission from the publisher or as permitted by law.

The open access publication of this volume is made possible by:

THE

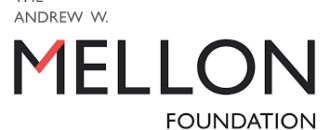

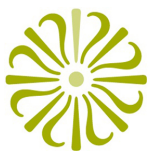

NATIONAL ENDOWMENT FOR THE HUMANITIES

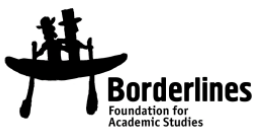

This open access publication is part of a project supported by the National Endowment for the Humanities and The Andrew W. Mellon Foundation Humanities Open Book initiative, which includes the open access release of several Academic Studies Press volumes. To view more titles available as free ebooks and to learn more about this project, please visit borderlinesfoundation.org/open.

Published by Academic Studies Press

28 Montfern Avenue

Brighton, MA 02135, USA

press@academicstudiespress.com

www.academicstudiespress.com 
A r s Rossika

Series Editor: David BETHEA

(University of Wisconsin - Madison and Oxford University)

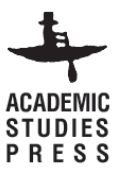

